\title{
Modeling the Influence of Group Norms and Self-regulatory Efficacy on Workplace Deviant Behaviour
}

\author{
Kabiru Maitama Kura ${ }^{1}$, Faridahwati Mohd. Shamsudin ${ }^{1} \&$ Ajay Chauhan ${ }^{1}$ \\ ${ }^{1}$ Othman Yeop Abdullah Graduate School of Business, Universiti Utara Malaysia, Malaysia \\ Correspondence: Kabiru Maitama Kura, Othman Yeop Abdullah Graduate School of Business, Universiti Utara \\ Malaysia, 06010 Sintok, Kedah, Malaysia. Tel: 60-16-489-6138. E-mail: km_kura@yahoo.co.uk
}

Received: January 10, 2013 Accepted: February 6, 2013 Online Published: March 28, 2013

doi:10.5539/ass.v9n4p113 URL: http://dx.doi.org/10.5539/ass.v9n4p113

\begin{abstract}
This study investigated the influence of group norms and self-regulatory efficacy on workplace deviant behaviour. A web-based survey was used to collect data from 217 teaching staff from various higher education institutions in Nigeria. The data collected was analysed using Partial Least Squares (PLS) path modeling. As predicted, the path coefficient results supported the direct influence of perceived injunctive norms and self-regulatory efficacy on organisational deviance. Similarly, perceived injunctive norm and self-regulatory efficacy were found to be significant predictors of interpersonal deviance. On the contrary, perceived descriptive norms were not significant predictors of both organisational deviance and interpersonal deviance. In addition, self-regulatory efficacy does not moderate the relationship between perceived descriptive norms and organisational deviance. We also found support for the moderating role of self-regulatory efficacy on the relationship between perceived injunctive norms and dimensions of workplace deviance. The moderating role of self-regulatory efficacy on the relationship between perceived descriptive norms and interpersonal deviance was also supported. Finally, the policy implications of the study are discussed.
\end{abstract}

Keywords: workplace deviance, perceived group norms, self-regulatory efficacy, social identity theory

\section{Introduction}

Workplace deviant behaviour is defined as a voluntary behaviour engaged by employee that is contrary to the significant organizational norms and it is considered as a threat to the well-being of an organization and/or its members (Robinson \& Bennett, 1995). Workplace deviance is pervasive phenomenon and costly to organisations (Aquino, Galperin, \& Bennett, 2004; Lawrence \& Robinson, 2007). Researchers have indicated that workplace deviant behaviour is potentially destructive or harmful to both organization and its members (Lawrence \& Robinson, 2007; Spector \& Fox, 2002). Workplace deviant behaviours violate the significant organizational norms as well as threatening the well-being of individual employees and the effective functioning of organisations (Ackroyd \& Thompson, 1999; Bennett \& Robinson, 2000, 2003; Fox \& Spector, 1999; Fox, Spector, \& Miles, 2001; Hollinger \& Clark, 1982; Nasir \& Bashir, 2012; Robinson \& Bennett, 1995; Sackett \& DeVore, 2001; Shamsudin, 2003; Vardi \& Weitz, 2004; Warren, 2003). For example, workplace deviance construct was reported to decrease labour productivity through absenteeism or lateness, and also damage organization's reputation, (Bowling \& Gruys, 2010). It was demonstrated that targets of interpersonal workplace deviance are more likely to experience work-related stress symptoms (e.g. psychological and physical pain), high turnover rate, lost work time, increased fear and insecurity in the workplace, low morale, damaged self-esteem and decreased productivity (Henle, Giacalone, \& Jurkiewicz, 2005). Furthermore, it was suggested that victims of workplace deviance are more likely to experience lower job satisfaction in relation to co-workers and supervisors, lower levels of psychological well-being, health satisfaction, relatively higher levels of psychological distress and higher levels of work withdrawal (Martin \& Hine, 2005).

Because of its significant costs, conducting a further study on its underlying causes is imperative. Therefore, the present study seeks to extend the existing workplace deviance literature by investigating the influence of group norms and self-regulatory efficacy on workplace deviant behaviour among the teaching staff from various higher education institutions in Nigeria. The remainder of this paper is organized as follows. In section 2, we highlighted on the issues in Nigerian higher education and then review the previous works that relate the theoretical constructs. To link these theoretical constructs, we use social learning theory as a basis. Hence, an 
elaboration of this theory was also offered. In section 3, we described the method used in the present study, followed by presentation of the results in section 4 . The final section captured discussion and implications of the study.

\section{Literature Review}

\subsection{The Nigerian Higher Education and Issues}

Higher education institutions are the third category of the Nigerian higher education system, comprising of conventional universities, open universities, colleges of education and polytechnics that prepares students for the world of work by providing them with an acceptable quality education (United Nations Educational Scientific and Cultural Organization, 2013). The Nigerian higher education system comprises of all organized learning and training activities at the post-secondary school level, including public and private universities, polytechnics and colleges of education and professional institutions such as law schools, colleges of medicine, police academy, institution of the military, Para-military institutions, schools of nursing, colleges of agriculture and non formal higher education, among others (Obanya, 1999). In Nigeria, higher education institutions are regulated by various statutory bodies responsible for quality assurance, accreditation of programmes and other related functions. These bodies include the Federal Ministry of Education (FME), National Universities Commission (NUC), National Board for Technical Education (NBTE) and National Commission for Colleges of Education (NCCE), among others. Despite these statutory bodies, higher education institutions have felt to deliver quality education to millions of Nigerians because of many problems that beset it.

One of the problems is with regards to workplace deviant behaviour (WDB), such as sexual harassment. The issue of the issue of sexual harassment has gained considerable media attention in recent years. For example, in a survey conducted on the prevalence of sexual harassment among 400 female students in University of Maiduguri, Nigeria, Geidam, Njoku and Bako (2011) reported that the rate of sexual harassment in Nigerian educational settings was high. The survey also revealed that 205 of the respondents, representing $51.3 \%$ of the sample, reported to have been sexually harassed. It is also reported that for several years, the incidences of sexual harassment in the Nigerian universities have been so rampant; still, little was done about this form WDB (Houreld, 2007).

\subsection{Empirical Studies}

Empirical studies regarding WDB have investigated group factors (e.g., Bamberger \& Biron, 2007; Dabney, 1995) and cognitive factors (Caprara, Regalia, \& Bandura, 2002; Caprara et al., 1998). However, there is a paucity of studies on the interaction between the two factors. The purpose of the present study is contribute to the existing body of knowledge by adopting an interactional approach to empirically investigate how individual's cognitive ability and group factors interact to explain why employees engage in deviant behaviour at the workplace. In particular, perceived group norms and self-regulatory efficacy are hypothesized to interact in explaining WDB. To explicate how group norms and self-regulatory efficacy interact to explain why employees engage in deviant behaviour at the workplace, we draw upon two perspectives: social learning theory (Bandura, 1978) and self-efficacy theory (Bandura, 1993, 1997). The social learning theory proposes that when individuals work in environments that is made up of referent others who serve as models for deviant behaviour, these individuals are more likely to engage in deviant behaviour because they are typically able to learn from their role model which gives them the opportunity engage in deviant acts (Robinson \& O'Leary-Kelly, 1998).

Empirical research provides considerable support for the social learning theory as a basis for understanding workplace deviance work (e.g., Bamberger \& Biron, 2007; Blanchard \& Henle, 2008; Kivlighan, Kivlighan, \& Cole, 2012; Salmivalli, 2010; Salmivalli \& Voeten, 2004). In particular, Elek, Miller-Day and Hecht (2006), which examined the effects of group norms on adolescent use of substance among 4,234 students. The findings of the study revealed that group norms (i.e. descriptive and injunctive norms) have strongest significant effect on adolescent use of substance. Similarly, Väänänen, Tordera, Kivimäki, Kouvonen, Pentti, Linna, and Vahtera (2008), the examined the effect of injunctive norms on sickness absence behaviour. The result of the study revealed that perceptions of work group members' permissive absence norms did not have effect on sickness absence behaviour. Kivlighan, Kivlighan and Cole (2012) also conducted a study to examine the interaction effect of commitment on the relationship between group members' absence norm and group member's absence for the next academic session. The study found that frequency of other group members absence is significant predictor of group member absence in the next academic session. Frone and Brown (2010) extended research on workplace deviance by conducting a study to investigate the influence of perceived group norms (i.e. descriptive norms and injunctive norms) on workplace substance use among 2,829 public service employees in United States. As predicted, the results of the study revealed that injunctive norm was significant predictor of substance 
use in the workplace. Conversely, descriptive workplace norm was not a significant predictor of illicit drug use after work. Based on the empirical evidences that have been presented above the following hypotheses are advanced:

H1: Perceived descriptive norm is positively related to organisational deviance.

H2: Perceived descriptive norm is positively related to interpersonal deviance.

H3: Perceived injunctive norm is positively related to organisational deviance.

H4: Perceived injunctive norm is positively related to interpersonal deviance.

Furthermore, on the basis of the mixed findings reported in the previous studies, the present study also adopted self-efficacy perspective (Bandura, 1993, 1997) to explain the direct and moderating effect of self-regulatory efficacy on the relationship between perceived group norms on workplace deviance. Self-regulatory efficacy is defined as an individual capacity to resist pressure from co-workers to engage in deviant acts (Caprara, et al., 2002). Therefore, self-efficacy theory (Bandura, 1993, 1997) postulates that an individual high in self-regulatory efficacy is less likely to engage in deviant behaviour than those that are low in self-regulatory efficacy. Additionally, incorporating self-regulatory efficacy in the present study is in line with Baron and Kenny's (1986) assertion that a moderator variable is usually incorporated when the relationship between a predictor and a criterion variable is found to be unexpectedly weak or inconsistent. Hence, in order to better understand the influence of group norms on workplace deviance, the present study suggests that self-regulatory efficacy might moderate the relationships.

Empirical studies have documented the effects of self-regulatory efficacy in minimizing the tendency for an individual to engage in deviant behaviour. For example, consistent with self-efficacy theory (Bandura, 1993, 1997), Caprara, Scabini, Barbaranelli, Pastorelli Regalia, and Bandura (1998) conducted a study to examine the impact of perceived self-regulatory efficacy on familial communication (open and problematic communication) and antisocial conduct among 324 adolescents from a residential community in Rome, who enrolled in various grades of high schools. The results of structural equation modelling (SEM) showed that students who were low in self-regulatory efficacy and academic self-efficacy are more likely to engage in antisocial conduct and substance abuse. Conversely, Caprara, Regalia and Bandura (2002) conducted a longitudinal study using SEM to investigate the impact of perceived self-regulatory efficacy on violent conduct among 350 adolescents from high schools in a residential community in Rome. The results of structural equation modelling revealed that students who were high in self-regulatory efficacy were less likely to engage in violent conduct such as fighting, vandalism, or used weapons. Hence, in line with these previous studies, it is reasonable to argue that the extent to which perceived group norms influence workplace deviant behaviour vary, depending upon an individual self-regulatory efficacy. On the basis of the foregoing discussion and empirical evidences the following hypotheses are proposed:

H5: Self-regulatory efficacy is negatively related to organisational deviance.

H6: Self-regulatory efficacy is negatively related to interpersonal deviance.

H7: Self-regulatory efficacy will moderate the relationship between perceived descriptive norms and organisational deviance.

H8: Self-regulatory efficacy will moderate the relationship between perceived descriptive norms and interpersonal deviance.

H9: Self-regulatory efficacy will moderate the relationship between perceived injunctive norms and organisational deviance.

H10: Self-regulatory efficacy will moderate the relationship between perceived injunctive norms and interpersonal deviance. 


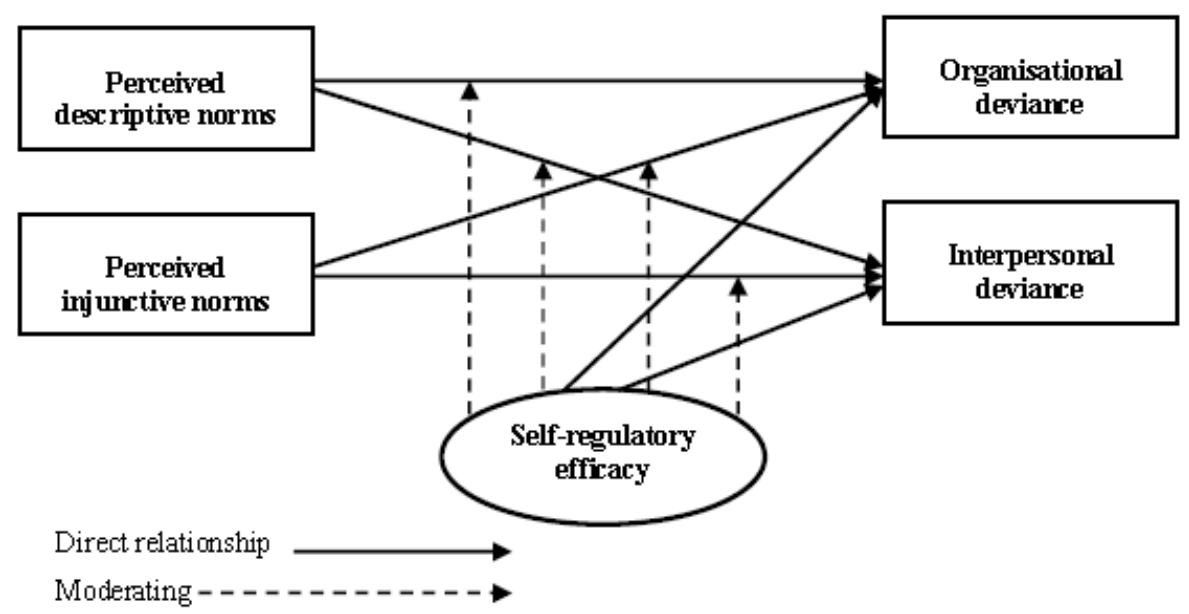

Figure 1. Research framework

\section{Method}

\subsection{Procedure and Participants}

Data for this study was collected via a web-based survey. The link to the web-based survey was emailed to the respondents. The survey included measures of workplace deviance, perceived group norms self-regulatory efficacy and demographic variables. Several reminders were sent to those respondents who were yet to complete a survey after two weeks via emails and mobile phone to increase response rates (Dillman, 2000; Porter, 2004). Participants were teaching staff from various higher education institutions in Nigeria, including universities, polytechnics and colleges of education. Two hundred and seventeen participants completed a survey, which was sufficient enough to run our analysis. Of 217 participants, majority were males (83.9\%). Majority of the participants, representing $75.1 \%$ were on the rank of senior lecturers and above, while the remaining respondents were below the rank of senior lecturer. Most of the respondents $(71.9 \%)$ hold Master's degree, $18.9 \%$ hold first degree (Bachelor/Higher National Diploma) and the remaining 9.2\% hold a doctorate degree. The mean age of the participants was about 36 years.

\subsection{Measures}

\subsubsection{Workplace Deviant Behaviour}

In the present study, 22-items was adapted from Bennett and. Robinson's (2000) workplace deviance scale to measure two dimensions of deviant behaviour in the workplace. In addition, 6 -items that are relevant to the lecturer's job in the Nigerian context were added to the workplace deviance scale. Examples of adapted items are: "discussed institution's confidential information with an unauthorized person", "spent most of his/her time attending to personal matters instead of official work." and "utilized school property for self-fish/private gain." All the respondents will rate themselves on the $28 \mathrm{WDB}$ items using 4-point Likert scale anchored by: $1=$ strongly disagree, 2 = disagree, $3=$ agree, and $4=$ strongly agree. The the use of Bennett and. Robinson's (2000) workplace deviance scale to assess deviant behaviour at work is justified because it has been found to be reliable in the previous studies, demonstrating internal reliability (Cronbach alpha) above the Nunnally's (1978) acceptable cutoff value of 0.70 and above (e.g., Diefendorff \& Mehta, 2007; Dunlop \& Lee, 2004; Judge, Scott, \& Ilies, 2006).

\subsubsection{Perceived Group Norm}

In the present study, 6-items Beliefs about Peer Norms Scale developed by Hansen and Graham (1991) was adapted to measure two empirically derived dimensions of perceived group norms: perceived injunctive norms and perceived descriptive norms. For injunctive norms subscale, respondents' perceptions were rated using 4-point Likert scale anchored by: $1=$ none of them, $2=$ fewer of them, $3=$ many of them, and $4=$ most of them. Examples of adapted items are: "how many of your colleagues do you think have attended to personal matters instead of official work during the past 30 days". Similarly, for descriptive norms subscale, respondents also rated their perception using using 4-point Likert scale anchored by: 1 = strongly disapprove, 2 = disapprove, $3=$ approve, and $4=$ strongly approve. Examples of adapted items are: "how would your colleagues' response if you engaged in negative act like sexual harassment and treating students badly?" Beliefs about peer norms scale was 
adapted in this study because previous studies have found it to be reliable (e.g., Kulis, Marsiglia, Nieri, Sicotte, \& Hohmann-Marriott, 2004; Wyrick et al., 2004).

\subsubsection{Self-regulatory Efficacy}

In the present study, 9-items were Adapted from Bandura's (1990) Self-Regulatory Efficacy Scale to measure Self-regulatory efficacy. Self-regulatory efficacy was assessed using using 4-point Likert scale anchored by: $1=$ not well at all, 2 = a little bit well, $3=$ very much well and $4=$ extremely well. Examples of adapted items are: "discussed institution's confidential information with an unauthorized person", "how well can you resist pressure to stop yourself from spending too much time attending to personal matters instead of official work?" and "How well can you prevent yourself from getting into too far joking with students?". Self-regulatory efficacy scale was adapted in this study because previous studies have found it to be reliable (e.g., Bandura, 1993).

\section{Results}

\subsection{Measurement Model}

In an attempt to ascertain the construct validity, we follow a two-step modeling approach as suggested by Anderson and Gerbing (1988). We started by assessing the convergent validity and reliability, followed by the discriminant validity, then internal consistency reliability as shown in Table 1 and Table 2 respectively. As a rule of thumb, construct validity is ascertained if the loadings are greater than 0.7 , composite reliability is greater than 0.7, average variance extracted is greater than 0.5 and Cronbach alpha is greater than 0.7(Bagozzi, Youjae, \& Phillips, 1991; Fornell \& Larcker, 1981; Gefen, Straub, \& Boudreau, 2000; Hair, Anderson, Tatham, \& Black, 1998; Nunnally, 1978).

Table 1. Results of measurement model

\begin{tabular}{lccccc}
\hline Model construct & Measurement item & Loadings & CR $^{a}$ & AVE $^{b}$ & Cronbach Alpha \\
\hline Interpersonal deviance & ID02 & 0.8 & 0.91 & 0.64 & 0.89 \\
& ID03 & 0.88 & & & \\
ID08 & 0.77 & & & \\
ID09 & 0.82 & & & \\
ID12 & 0.75 & & & 0.91 \\
Organisational deviance & ID13 & 0.79 & & & \\
& OD08 & 0.89 & 0.93 & 0.73 & \\
OD09 & 0.77 & & & \\
Perceived descriptive norms & OD10 & 0.85 & & & \\
Perceived injunctive norms & OD11 & 0.85 & & & \multirow{2}{*}{0.75} \\
& OD12 & 0.92 & & & \\
Self-regulatory efficacy & PDN01 & 0.95 & 0.85 & 0.74 & \\
& PDN02 & 0.76 & & & \\
& PIN01 & 0.75 & 0.86 & 0.67 & \\
& PIN02 & 0.9 & & & \\
& PIN03 & 0.79 & & & \\
& SRE01 & 0.74 & 0.9 & 0.65 & \\
& SRE02 & 0.87 & & & \\
& SRE03 & 0.7 & & & \\
& SRE04 & 0.86 & & & \\
& SRE09 & 0.85 & & & \\
\hline
\end{tabular}

Note: ID01, ID04, ID05, ID06, ID07, ID10, ID011, OD01, OD02, OD03, OD04, OD05, OD06, OD07, OD13, OD14, SRE06, SRE07 and SRE08 were deleted because of low loadings of less than 0.50; aComposite Reliability $(\mathrm{CR})=$ (square of the summation of the factor loadings)/[(square of the summation of the factor loadings) + (square of the summation of the error variances)]; bAverage Variance Extracted (AVE) $=($ summation of the square of the factor loadings)/[(summation of the square of the factor loadings) + (summation of the error variances)]. 
We also conducted the discriminant validity following the Fornell and Lacker's (1981) recommendation. On the basis of this recommendation, the average variance shared between each construct and its measures should exceed the variance shared between the construct and other constructs(Fornell \& Larcker, 1981).

Table 2. Discriminant validity of constructs

\begin{tabular}{llllll}
\hline Constructs & $\mathbf{1}$ & $\mathbf{2}$ & $\mathbf{3}$ & $\mathbf{4}$ & $\mathbf{5}$ \\
\hline Interpersonal deviance & $\mathbf{0 . 8 0}$ & & & & \\
Organisational deviance & 0.63 & $\mathbf{0 . 8 6}$ & & & \\
Perceived descriptive norms & 0.17 & 0.17 & $\mathbf{0 . 8 6}$ & & $\mathbf{0 . 8 2}$ \\
Perceived injunctive norms & 0.78 & 0.68 & 0.09 & 0.29 & $\mathbf{0 . 8 1}$ \\
Self-regulatory efficacy & -0.42 & -0.35 & 0.18 & \\
\hline
\end{tabular}

Note: Diagonals (bold face) represent the square root of the average variance extracted while the other entries represent the correlations.

As evidenced in Table 2 above, the correlations for each construct is less than the square root of the average variance extracted suggesting adequate discriminant validity of the construct (Hair, et al., 1998; Hair, Black, Babin \& Anderson, 2010).

\subsection{Structural Model}

Following the measurement model next was the structural model. The results are presented in Table 3 and Figure 2. The R2 values were 0.49 and 0.65 which suggest that the modeled variables can explain $49 \%$ and $65 \%$ of the variance of the organisational deviance and interpersonal deviance respectively.

Table 3. Path coefficients and hypothesis testing

\begin{tabular}{llllll}
\hline Hypothesis & Relations & Beta & Standard Error & T-Statistics & Findings \\
\hline H1 & PDN -> OD & 0.08 & 0.05 & 1.67 & Not supported \\
H2 & PDN -> ID & 0.06 & 0.04 & 1.55 & Not supported \\
H3 & PIN -> OD & 0.62 & 0.04 & 14.49 & Supported \\
H4 & PIN -> ID & 0.71 & 0.03 & 23.61 & Supported \\
H5 & SRE -> OD & -0.16 & 0.06 & 2.67 & Supported \\
H6 & SRE -> ID & -0.21 & 0.04 & 5.15 & Supported \\
H7 & PDN * SRE -> OD & -0.10 & 0.06 & 1.69 & Not moderating \\
H8 & PDN * SRE -> ID & -0.08 & 0.04 & 2.06 & Moderating \\
H9 & PIN * SRE -> OD & -0.44 & 0.09 & 5.09 & Moderating \\
H10 & PIN * SRE -> ID & -0.24 & 0.06 & 3.98 & Moderating \\
Organisational deviance (R ${ }^{2}=49 \%$ & & & & \\
Interpersonal deviance $\quad\left(\mathrm{R}^{2}\right)$ & $=65 \%$ & & & \\
\hline
\end{tabular}

Note: ${ }^{*} \mathrm{p}<0.05 ; * * \mathrm{p}<0.01$ 


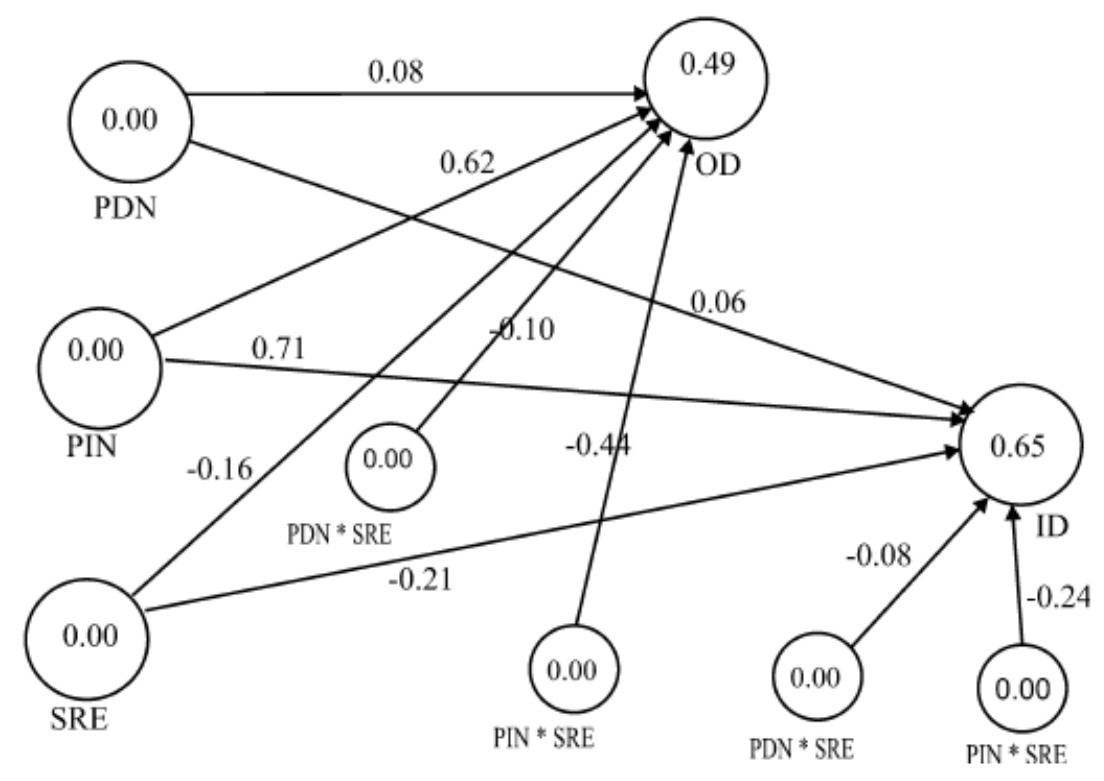

Figure 2. Results of the structural model analysis

As shown in Table 3 and figure 2, hypotheses 1, 3, 4, 5, 6, 8, 9 and 10) were supported, while on the contrary, hypotheses 1,2 , and 7 were not supported.

\section{Discussion}

This study investigated the influence of group norms and self-regulatory efficacy on workplace deviant behaviour among teaching staff from various higher education institutions in Nigeria. The results of this study indicated that perceived injunctive norm was related to workplace deviance in expected direction. In particular, perceived injunctive norm was related negatively to dimensions of workplace deviance (interpersonal deviance and organisational deviance). This findings is consistent with results of previous research (e.g., Elek, et al., 2006; Frone \& Brown, 2010). This implies that when employee learns that many of his colleagues WDB, he is more likely to engage in such negative behaviour because of the strong influence of group on individual members (Robinson \& O'Leary-Kelly, 1998). This study also provided empirical support for the direct relationship between self-regulatory efficacy and WDB. Specifically, self-regulatory efficacy has a negative effect on workplace deviance (e.g., Caprara, et al., 2002; Caprara, et al., 1998). Drawing upon the self-efficacy theory (Bandura, 1993, 1997), individual high in self-regulatory efficacy are less likely to commit deviant act than those who are low in self-regulatory efficacy.

On the contrary, the finding of this study also revealed that perceived descriptive norms were not significant predictors of workplace deviant behaviour. This finding is not surprising, because it appears to be consistent with the study of Frone (2010), who found that descriptive workplace norm was not a significant predictor of illicit drug use after work. One possible explanation for the non-significant relationship between perceived descriptive norms and WDB may have to do with the salience of different norms in different contexts (Frone \& Brown, 2010). Thus, what others do in a given situation may not be applicable in another situation. The significant influence of descriptive norms on WDB is contingent upon the context of the study. Self-regulatory efficacy was not found to moderate the relationship between perceived descriptive norms and workplace deviant behaviour.

\subsection{Implications}

On the basis of the above findings and discussion, there are few implications for management of the higher education institutions and their employees considering the important of teaching and research. The significant negative relationship between self-regulatory efficacy and workplace deviance suggest that individual cognitive ability is an important stable resource in enhancing reducing the tendency of individual to engage in deviant behaviour deviance (Caprara, et al., 2002; Caprara, et al., 1998). Therefore, universities and colleges ought to the use of personality inventory test during the selection methods to enable them employ staffs that are high in self-efficacy. The universities and colleges should identify those candidates who are high in self-efficacy during recruitment and selection process and then offer ethical orientation to those identified. In addition to cognitive 
ability (self-efficacy), ethical orientation can also reduce the tendency of individual to engage in deviant behaviour deviance (Henle, et al., 2005).

This present study has certain limitations that need to be acknowledged. First, this study reported $\mathrm{R}^{2}$ values of $49 \%$ to $65 \%$ of the variance of the organisational deviance and interpersonal deviance respectively, suggesting that perceived group norms and self-regulatory efficacy are not the only predictors of deviant behaviour in the workplace. Therefore, future study should incorporate other variables such as organizational formal control and self-control. Second, this study was a cross-sectional in nature. Hence, conclusions regarding the causal nature of the research model cannot be made. Therefore, future studies should also be conducted using longitudinal study in order to confirm the findings of this study. Third, this study only considered teaching staff; future studies should include non-teaching staff in their sample because deviant acts are not committed by only teaching staff. Hence including non teaching staff will make it possible to generalize the findings. Finally, it must be acknowledged that self-reported measures were used to collect data for this study and these measures are often associated with social desirability and/or common method bias. Therefore, future study should include multiple sources, such as peers, subordinates and supervisors to assess deviant behaviours (Conway \& Huffcutt, 1997; Hooft, Flier, \& Minne, 2006; Porr \& Fields, 2006; Sargeant, 2006).

\section{References}

Ackroyd, S., \& Thompson, P. (1999). Organizational misbehaviour. London: Sage Publications Ltd.

Anderson, J. C., \& Gerbing, D. W. (1988). Structural equation modeling in practice: A review and recommended two-step approach. Psychological Bulletin, 103, 411-423. http://dx.doi.org/10.1037/0033-2909.103.3.411

Aquino, K., Galperin, B. L., \& Bennett, R. J. (2004). Social status and aggressiveness as moderators of the relationship between interactional justice and workplace deviance. Journal of Applied Social Psychology, 34, 1001-1029. http://dx.doi.org/10.1111/j.1559-1816.2004.tb02581.x

Bagozzi, R. P., Youjae, Y., \& Phillips, L. W. (1991). Assessing construct validity in organizational research. Administrative Science Quarterly, 36, 421-458. http://dx.doi.org/10.2307/2393203

Bamberger, P., \& Biron, M. (2007). Group norms and excessive absenteeism: The role of peer referent others. Organizational Behavior and Human Decision Processes, 103, 179-196. http://dx.doi.org/10.1016/j.obhdp.2007.03.003

Bandura, A. (1978). Social Learning Theory of Aggression. Journal of Communication, 28(3), 12-29. http://dx.doi.org/10.1111/j.1460-2466.1978.tb01621.x

Bandura, A. (1993). Perceived self-efficacy in cognitive development and functioning. Educational Psychologist, 28(2), 117-148. http://dx.doi.org/10.1207/s15326985ep2802_3

Bandura, A. (1997). Self-efficacy: The exercise of control. New York: W. H. Freeman and Company.

Baron, R. M., \& Kenny, D. A. (1986). The moderator-mediator variable distinction in social psychological research: Conceptual, strategic, and statistical considerations. Journal of personality and social psychology, 51, 1173-1182. http://dx.doi.org/10.1037/0022-3514.51.6.1173

Bennett, R. J., \& Robinson, S. L. (2000). Development of a measure of workplace deviance. Journal of Applied Psychology, 85, 349-360. http://dx.doi.org/10.1037/0021-9010.85.3.349

Bennett, R. J., \& Robinson, S. L. (2003). The past, present, and future of workplace deviance research.

Blanchard, A. L., \& Henle, C. A. (2008). Correlates of different forms of cyberloafing: The role of norms and external locus of control. Computers in Human Behavior, 24, 1067-1084. http://dx.doi.org/10.1016/j.chb.2007.03.008

Bowling, N. A., \& Gruys, M. L. (2010). Overlooked issues in the conceptualization and measurement of counterproductive work behaviour. Human Resource Management Review, 20(1), 54-61. http://dx.doi.org/10.1016/j.hrmr.2009.03.008

Caprara, G. V., Regalia, C., \& Bandura, A. (2002). Longitudinal impact of perceived self-regulatory efficacy on violent conduct. European Psychologist, 7(1), 63-69. http://dx.doi.org/10.1027//1016-9040.7.1.63

Caprara, G. V., Scabini, E., Barbaranelli, C., Pastorelli, C., Regalia, C., \& Bandura, A. (1998). Impact of adolescents' perceived self-regulatory efficacy on familial communication and antisocial conduct. European Psychologist, 3, 125-132. http://dx.doi.org/10.1027//1016-9040.3.2.125

Conway, J. M., \& Huffcutt, A. I. (1997). Psychometric properties of multisource performance ratings: A 
meta-analysis of subordinate, supervisor, peer, and self-ratings. Human Performance, 10, 331-360. http://dx.doi.org/10.1207/s15327043hup1004_2

Dabney, D. (1995). Workplace deviance among nurses: The influence of work group norms on drug diversion and/or use. Journal of Nursing Administration, 25(3), 48-55. http://dx.doi.org/10.1097/00005110-199503000-00009

Diefendorff, J. M., \& Mehta, K. (2007). The relations of motivational traits with workplace deviance. Journal of Applied Psychology, 92, 967-977. http://dx.doi.org/10.1037/0021-9010.92.4.967

Dillman, D. A. (2000). Mail and Internet surveys: The tailored design method (2nd ed.). New York: John Wiley \& Sons, Inc.

Dunlop, P. D., \& Lee, K. (2004). Workplace deviance, organizational citizenship behavior, and business unit performance: the bad apples do spoil the whole barrel. Journal of Organizational Behavior, 25, 67-80. http://dx.doi.org/10.1002/job.243

Eder, P., \& Eisenberger, R. (2008). Perceived organizational support: Reducing the negative influence of coworker withdrawal behavior. Journal of Management, 34(1), 55-68. http://dx.doi.org/10.1177/0149206307309259

Elek, E., Miller-Day, M., \& Hecht, M. L. (2006). Influences of personal, injunctive, and descriptive norms on early adolescent substance use. Journal of Drug Issues, 36, 147-171. http://dx.doi.org/10.1177/002204260603600107

Fornell, C., \& Larcker, D. F. (1981). Evaluating Structural Equation Models with unobservable variables and measurement error. Journal of Marketing Research, 18(1), 39-50. http://dx.doi.org/10.2307/3151312

Fox, S., \& Spector, P. E. (1999). A model of work frustration-aggression. Journal of Organizational Behavior, 20(6), 915-931. http://dx.doi.org/10.1002/(SICI)1099-1379(199911)20:6<915::AID-JOB918>3.0.CO;2-6

Fox, S., Spector, P. E., \& Miles, D. (2001). Counterproductive work behaviour (CWB) in response to job stressors and organizational justice: Some mediator and moderator tests for autonomy and emotions. Journal of Vocational Behavior, 59, 291-309. http://dx.doi.org/10.1006/jvbe.2001.1803

Frone, M. R., \& Brown, A. L. (2010). Workplace substance-use norms as predictors of employee substance use and impairment: a survey of US workers. Journal of Studies on Alcohol and Drugs, 71, 526-534.

Gefen, D., Straub, D. W., \& Boudreau, M. C. (2000). Structural equation modeling and regression: Guidelines for research practice. Communications of the Association for Information Systems, 4(7), 1-70.

Geidam, A. D., Njoku, A. E., \& Bako, B. (2011). Prevalence and nature of sexual assault among female students in a Tertiary Institution in Maiduguri, Nigeria - A Cross sectional study. International Journal of Health Research, 3, 199-203. http://dx.doi.org/10.4314/ijhr.v3i4.70422

Hair, J. F., Anderson, R. E., Tatham, R. L., \& Black, W. C. (1998). Multivariate Data Analysis (5th ed.). Upper Saddle River, New Jersey: Prentice Hall.

Hair, J. F., Black, W. C., Babin, B. J., \& Anderson, R. E. (2010). Multivariate data analysis (7th ed.). Upper Saddle River, New Jersey: Prentice Hall.

Henle, C. A., Giacalone, R. A., \& Jurkiewicz, C. L. (2005). The Role of Ethical Ideology in Workplace Deviance. Journal of Business Ethics, 56, 219-230. http://dx.doi.org/10.1007/s10551-004-2779-8

Hollinger, R. C., \& Clark, J. P. (1982). Formal and informal social controls of employee deviance. The Sociological Quarterly, 23, 333-343. http://dx.doi.org/10.1111/j.1533-8525.1982.tb01016.x

Hooft, E. A. J., Flier, H., \& Minne, M. R. (2006). Construct validity of multi-source performance ratings: An examination of the relationship of self, supervisor, and peer-ratings with cognitive and personality measures. International Journal of Selection and Assessment, 14(1), 67-81. http://dx.doi.org/10.1111/j.1468-2389.2006.00334.x

Houreld, K. (2007, March 25). Sexual harassment plagues Nigeria's schools. Los Angeles Times. Retrieved from http://articles.latimes.com/2007/mar/25/news/adfg-lecherous25

Judge, T. A., Scott, B. A., \& Ilies, R. (2006). Hostility, job attitudes. http://dx.doi.org/10.1037/0021-9010.91.1.126

Kivlighan, D. M., Kivlighan, D. M., \& Cole, O. D. (2012). The group's absence norm and commitment to the group as predictors of group member absence in the next session: An actor-partner analysis. Journal of 
Counseling Psychology, 59(1), 41-49. http://dx.doi.org/10.1037/a0025506

Kulis, S., Marsiglia, F. F., Nieri, T., Sicotte, D., \& Hohmann-Marriott, B. (2004). Majority rules? The effects of school ethnic composition on substance use by Mexican heritage adolescents. Sociological focus, 37(4), 371-392. http://dx.doi.org/10.1080/00380237.2004.10571252

Lawrence, T. B., \& Robinson, S. L. (2007). Ain't misbehavin: Workplace deviance as organizational resistance. Journal of Management, 33, 378-394. http://dx.doi.org/10.1177/0149206307300816

Martin, R. J., \& Hine, D. W. (2005). Development and validation of the Uncivil Workplace Behavior Questionnaire. Journal of Occupational Health Psychology, 10, 477-490. http://dx.doi.org/10.1037/1076-8998.10.4.477

Nasir, M., \& Bashir, A. (2012). Examining workplace deviance in public sector organizations of Pakistan. International Journal of Social Economics, 39(4), 240-253. http://dx.doi.org/10.1108/03068291211205677

Nunnally, J. C. (1978). Psychometric theory (2nd ed.). New York: McGraw-Hill.

Obanya, P. (1999). Higher Education for an Emergent Nigeria: Faculty of Education, University of Ibadan 5th Anniversary Lecture. Ibadan: Heinemann Education Books (Nigeria Plc).

Porr, D., \& Fields, D. (2006). Implicit leadership effects on multi-source ratings for management development. Journal of Managerial Psychology, 21, 651-668. http://dx.doi.org/10.1108/02683940610690196

Porter, S. R. (2004). Raising response rates: what works? In S. R. Porter (Ed.), Overcoming survey research problems. New Directions for Institutional Research (pp. 5-22). San Francisco: Jossey-Bass.

Robinson, S. L., \& Bennett, R. J. (1995). A typology of deviant workplace behaviors: A multidimensional scaling study. Academy of Management Journal, 38, 555-572. http://dx.doi.org/10.2307/256693

Robinson, S. L., \& O'Leary-Kelly, A. M. (1998). Monkey see, monkey do: The influence of work groups on the antisocial behavior of employees. Academy of Management Journal, 658-672. http://dx.doi.org/10.2307/256963

Sackett, P. R., \& DeVore, C. J. (2001). Counterproductive behaviours at work. In D. O. N. Anderson, H. Sinangil, \& C. Viswesvaran (Eds.), Handbook of industrial, work and organizational psychology: Personnel psychology (Vol. 1, pp. 145-164). London: Sage Publications. http://dx.doi.org/10.4135/9781848608320.n9

Salmivalli, C. (2010). Bullying and the peer group: A review. Aggression and Violent Behavior, 15(2), 112-120. http://dx.doi.org/10.1016/j.avb.2009.08.007

Salmivalli, C., \& Voeten, M. (2004). Connections between attitudes, group norms, and behaviour in bullying situations. International Journal of Behavioral Development, 28, 246-258. http://dx.doi.org/10.1080/01650250344000488

Sargeant, J. (2006). Multi-source feedback for physician learning and change. Nova Scotia, Canada: Halcraft Printers Inc.

Shamsudin, F. M. (2003). Workplace deviance among hotel employees: An exploratory survey. Malaysian Management Journal, 7(1), 17-33.

Spector, P. E., \& Fox, S. (2002). An emotion-centered model of voluntary work behaviour - Some parallels between counterproductive work behaviour and organizational citizenship behaviour. Human Resource Management Review, 12, 269-292. http://dx.doi.org/10.1016/s1053-4822(02)00049-9

United Nations Educational Scientific and Cultural Organization. (2013). Education. Retrieved February 5, 2013 from http://www.unesco.org/new/en/education/resources/unesco-portal-to-recognized-higher-education-institutio ns/dynamic-single-view/news/nigeria/

Vardi, Y., \& Weitz, E. (2004). Misbehavior in organizations: Theory, research, and management. Lawrence Erlbaum.

Warren, D. E. (2003). Constructive and destructive deviance in organizations. The Academy of Management Review, 622-632.

Wyrick, D. L., Wyrick, C. H., Bishop, D., Fearnow-Kenney, M. D., Hardy, C. Y., \& Hansen, W. B. (2004). Health-related social norms among high school students. The Health Educator, 36(2), 3-7. 